\title{
Ambiguidade do amor-próprio e formação virtuosa da vontade
}

\author{
Self-love ambiguity and virtuous will-formation \\ Ambigüedad del amor propio y formación virtuosa de la voluntad
}

\begin{abstract}
Claudio Almir Dalbosco*
$\diamond$

RESUMO - O ensaio investiga o problema da condição humana em Rousseau. O sentimento do amor por si mesmo, constituído duplamente pelo amor de si e pelo amor-próprio, é tomado como núcleo da pergunta sobre "quem é o ser humano?". O trabalho analisa duas interpretações standard sobre o tema: a posição de Iring Fetscher, que destaca somente a variante negativa do amor-próprio e a interpretação recente de Frederick Neuhouser, que atribui ao amorpróprio também uma força construtiva. Se a possibilidade de paixões odientas e irascíveis é inerente à condição humana, ela também pode ser dominada por paixões tenras e amorosas. O ensaio argumenta ainda que embora nem tudo se decida no âmbito educacional, o tipo de educação oferecido na infância cobra importância capital na futura formação moral do adulto. A educação pode, por um lado, estimular um modo de ação baseado mais em paixões maldosas e egoístas ou, por outro, paixões amorosas e solidárias.
\end{abstract}

Palavras-chave - Amor de si. Amor-próprio. Educação. Formação humana.

ABSTRACT - The paper concerns the problem of the human condition in Rousseau. The feeling of love for the self, double constituted by the amour de soi and amour propre, is taken as the core question 'who is the human being?'. It analyzes two standard interpretations of the theme: Iring Fetscher's position, highlighting only the negative variant of amour propre and Frederick Neuhouser's recent interpretation that also attaches to amour propre a constructive force. If the possibility of hateful and irascible passions is inherent in the human condition, it can also be dominated by tender and amorous passions. The essay argues that even though not everything is decided in the educational field, the type of education offered in childhood demands great importance in the adult's moral education. On one side, it can encourage a way of more based on malicious and selfish passions or on the other side, loving and supportive action.

Keywords - Amour de soi. Amour propre. Education. Human development.

RESUMEN - Este ensayo investiga el problema de la condición humana en Rousseau. El sentimiento del amor en sí mismo, constituido doblemente por el amor de sí y por el amor propio, se toma como núcleo de la pregunta "quién es el ser humano?". El trabajo analiza dos interpretaciones standard sobre el tema: la posición de Iring Fetscher, que destaca solamente la variante negativa del amor propio, y la interpretación reciente de Frederick Neuhouer, que atribuye al amor propio también una fuerza constructiva. Si la posibilidad de pasiones malévolas e irascibles es inherente a la condición humana, ella puede, asimismo, ser dominada por pasiones tiernas y amorosas. El ensayo incluso argumenta que, aunque no todo se decida en el ámbito educacional, el tipo de educación ofrecido en la infancia cobra importancia capital en la futura formación moral del adulto. La educación puede estimular un modo de acción basado en pasiones maldosas y egoístas, o bien pasiones amorosas y solidarias.

Palabras clave - Amor de sí. Amor próprio. Educación. Formación humana.

O homem bom ordena-se em relação ao todo, e o mau ordena o todo em relação a si mesmo. Esse último faz de si mesmo o centro de todas as coisas; o primeiro mede-se e mantém-se na circunferência.

(ROUSSEAU, OC IV, 602)

\footnotetext{
* Doutor em Filosofia pela Universidade de Kassel (Kassel, Alemanha) e professor na Universidade de Passo Fundo (Passo Fundo, RS, Brasil). E-mail: <vcdalbosco@hotmail.com>.
} 


\section{INTRODUÇÃO}

Compreender como se entrelaçam maldade humana e estruturas sociais e institucionais corruptas é, desde a antiguidade, uma questão central que preocupa o pensamento humano. Buscar entender, por exemplo, como se gera violência e destruição dentro da escola ou como a política se torna corrupta no modelo atual de democracia representativa são preocupações que deveriam estar na pauta do dia de todos os educadores. Esses temas se vinculam a questões profundas e difíceis que estão muito longe de terem sido solucionadas: de onde se origina o mal humano? Por que o ser humano se deixa orientar por suas paixões maldosas, cometendo em nome delas crimes horrendos? O que o leva naturalizar seu sentimento de superioridade escravizante em relação ao seu semelhante, sentindo-se interiormente muito confortável e realizado por pisoteá-lo? Como contrapor-se individual e coletivamente ao mal? Que papel a educação pode desempenhar contra a maldade humana e a corrupção social e política? Por que a educação contra a maldade é fundamental à construção de uma comunidade ética? Em que sentido as teorias educacionais podem auxiliar no esclarecimento da origem e natureza da maldade humana e de sua correlação com a corrupção social e política? Que processos formativos elas podem desencadear visando ao enfrentamento ético do mal inerente à condição social humana?

Este amplo questionamento indica que o problema da maldade humana, muito longe de ser um tema meramente "abstrato", tem repercussão direta na vida cotidiana dos indivíduos, relacionando-se com a ordem social e cultural. Portanto, o mal se radica na condição humana e possui uma faceta tanto social como moral. Ora, é justamente esta tríplice dimensão interligada entre si - humana, social e moral - que o torna um problema educacional por excelência, sobretudo, quando vinculado aos vícios do caráter. Para muitos filósofos e pensadores, os vícios só podem ser evitados por uma educação virtuosa, pois é ela que oferece a força necessária para o domínio das paixões maldosas.

No presente ensaio pretendo tratar desta temática reportando-me ao pensamento de Jean-Jacques Rousseau. Tomo-o como referência não porque penso que tenha resolvido o problema da maldade humana ou porque sua teoria educacional seja a melhor. Ele se torna indispensável porque foi um dos primeiros, entre os modernos, a esboçar a teoria secularizada do mal humano, radicando-o primeiramente na própria condição social do ser humano. Além disso, também está entre os primeiros a inserir concretamente o problema do mal humano no âmbito de uma teoria educacional, pensando ideias, princípios e estratégias pedagógicas visando preparar educando e educador para enfrentar adequadamente o cerne da maldade humana e social.

Como veremos logo abaixo, Rousseau compreende o mal humano no contexto de sua teoria da ambiguidade do amor-próprio e vê a possibilidade de contorná-lo por meio da virtude. Como o mal humano está diretamente vinculado aos vícios, contra eles deve ser desencadeado o processo educacional orientado pela virtude. Em síntese, segundo Rousseau, se o amor-próprio excessivo (inflamado) é a principal fonte da maldade humana, a educação virtuosa deve ser seu principal antídoto.

Muitos problemas estão vinculados à ambiguidade do amor-próprio e à teoria da virtude propostas por Rousseau. Alguns autores discordam de sua concepção de virtude, criticando a obscuridade de seus conceitos de vontade e consciência. Outros ignoram a ambiguidade do amor-próprio, não considerando devidamente sua proposta educativa. Há também aqueles que negam o vínculo entre ambiguidade do amor-próprio e formação virtuosa da vontade. Por fim, outros ainda condenam suas ideias educacionais por causa de sua dependência à noção iluminista do sujeito racional autônomo.

Obviamente que está fora do meu alcance abordar neste breve ensaio o conjunto de questões postas acima e também tratar das divergências e polêmicas que reinam disseminadamente entre os especialistas do pensamento de Rousseau. Ao invés disso, vou me concentrar na ambiguidade do amor-próprio e na necessidade de educálo por meio da virtude. Além de me limitar ao texto de Rousseau, também vou me reportar pontualmente a Iring Fetscher (1975) e Frederick Neuhouser (2012). As razões de inseri-los na minha abordagem ficarão claras logo abaixo.

Adoto, para tratar dos textos e autores indicados, o procedimento hermenêutico, o qual não deve ser confundido nem com o procedimento analítico nem com o meramente descritivo. Entendo por procedimento hermenêutico, nesse contexto, a relação interpretativa que se estabelece entre o investigador e o texto investigado. ${ }^{1}$ Sob esse aspecto, considero dois procedimentos hermenêuticos como fundamentais: o primeiro consiste em entregar-se ao texto, escutando o que ele tem a dizer e deixando-se impregnar pelo processo de estranhamento que ele causa. Trata-se de evitar, nesse sentido, o procedimento usual de simplesmente impor ao texto algo estabelecido previamente, ou seja, de quer fazê-lo responder somente às inquietações do investigador (leitor). O segundo procedimento, decorrente do primeiro, referese à necessidade que o investigador possui, orientando-se pela escuta, de pôr questões ao texto, fazendo-o respondêlas. Segundo Flickinger: "É o próprio texto que nos leva a colocar-lhe perguntas adequadas; que conseguem abrilo à nossa compreensão. Por isso mesmo, a pergunta 
adequada é mais importante e difícil do que a resposta certa" (FLICKINGER, 2010, p. 36).

Esses dois procedimentos contêm o núcleo hermenêutico do que entendo por tratamento interpretativo do texto investigado: o processo inicial do investigador de se deixar estranhar pelo sentido do texto e, simultaneamente, a irrupção autônoma do investigador, na medida em que provoca o texto a responder às perguntas postas pelo próprio investigador ao entregar-se à leitura. Nesse sentido, concebo a pergunta como aspecto estruturante não só da relação entre investigador e texto, como também da própria construção do problema de investigação que orienta o ensaio ou, em sentido mais amplo, o projeto de investigação. $^{2}$

$\mathrm{Na}$ sequência, prossigo argumentando em dois passos. No primeiro, resumo o núcleo da interpretação do amor-próprio que o concebe somente em sua variante negativa, tomando o estudo de Iring Fetscher (1975) como modelo paradigmático. Com isso pretendo deixar claro que uma interpretação, como a de Fetscher, que não leva em conta a variante positiva do amor-próprio, termina por não compreender adequadamente a própria teoria da virtude e seu papel educacional. No segundo, passo da argumentação, amparando-me na nova interpretação de Neuhouser, busco reconstruir o núcleo da teoria da ambiguidade do amor-próprio em Rousseau, mostrando, na sequência, seu vínculo estreito com o problema da educação virtuosa. Por fim, concluo o ensaio enfatizando a importância da reflexão sobre os clássicos na formação das novas gerações. Diante disso, põe-se o problema da atualização de seu pensamento e, no caso específico de Rousseau, a exigência de pensar o nexo indissociável entre educação virtuosa e modelo republicano como modo crítico de desfazer a imbricação fatal entre paixões maldosas e corrupção social e política.

\section{MALDADE DO AMOR-PRÓPRIO E INSUFICIÊNCIA DO AMOR À ORDEM}

A enorme influência que a obra de Rousseau exerceu na Europa e no mundo todo não é nenhuma novidade. Ainda em vida, desempenhou uma força de atração muito grande entre os pensadores alemães: iniciando com Kant, passa por Herder e deságua no movimento da Sturm und Drang (tempestade e ímpeto). É conhecida a anedota de que somente ele, com a publicação do Émile, foi capaz de interromper a caminhada rotineira do filósofo prussiano, altamente disciplinado. Anedota ou não, Kant o tinha em alta conta, a tal ponto de considerá-lo o Newton da moral. Neste sentido, o próprio Kant marca o início de uma intensa e contínua recepção dos pensadores alemães: quer seja para condenar ou elogiar seu pensamento, eles não deixavam de ler seus escritos.
$\mathrm{Na}$ atualidade, Axel Honneth, o segundo mais influente na hierarquia dos pensadores frankfurtianos ainda vivos, ficando atrás somente de Jürgen Habermas, atribui a Rousseau o mérito de ser pioneiro na formulação do conceito moderno de liberdade reflexiva (HONNETH, 2011). ${ }^{3}$ Se Honneth não nega o papel que o genebrino desempenha na formulação de sua teoria da justiça, Iring Fetscher, décadas anteriores, também lhe atribui lugar de destaque na ampla tradição do pensamento político moderno. Com base no hábil manuseio das obras de Rousseau, Fetscher oferece ampla exposição de sua filosofia política, concentrando-se na noção de república. Contudo, seu estilo hermenêutico cuidadoso não o impediu de cometer um erro elementar: considera somente a variante negativa do amor-próprio, desconsiderando sua dimensão construtiva (positiva). Como isso é um problema importante que tem interferência direta na interpretação da teoria educacional de Rousseau e, por conseguinte, respinga no tratamento a ser dado ao problema do mal humano e da corrupção social, preciso analisar brevemente como o referido autor comete este equívoco.

Fetscher trata pontualmente do tema no segundo capítulo de seu livro Filosofia política de Rousseau (Rousseaus politische Philosophie). É no contexto de sua exposição da ética e da antropologia rousseauniana que ele se reporta ao conceito de amor-próprio. Reconhece acertadamente que a preocupação pela condição humana está na raiz da crítica rousseauniana à cultura e à sociedade. Ou seja, mostra que a investigação sobre a origem da desigualdade entre os homens só é possível de ser conduzida, na direção correta se estiver orientada pela pergunta sobre quem é o ser humano. E, para desvendála, Rousseau põe o sentimento do amor por si mesmo (amour de soi) como núcleo da condição humana: foi o amor por si mesmo que impulsionou o homem primitivo à socialização e à ampla criação cultural.

Permanecendo colado ao texto do Segundo Discurso, ${ }^{4}$ Fetscher vê no amor por si mesmo o impulso buscado pelo ser humano para construir seu laço social. Na medida em que sentiu a necessidade de ser reconhecido pelo outro, de fazer sua própria autoestima depender do olhar do outro, o ser humano não foi mais capaz de viver sozinho, entrando em processo permanente e inesgotável de dependência recíproca. Esta estrutura profunda da condição humana, do amor por si mesmo, desdobra-se, numa dupla vertente, no amor de si e no amor-próprio. Fetscher compreende adequadamente o amor de si, definindo-o como princípio de autoconservação. $\mathrm{O}$ amor de si é o instinto de pulsão dado pela natureza a todo o ser vivo para preservar sua vida, valendo isso então igualmente ao ser humano. Ou seja, o amor de si é o sentimento instintivo lançado mão pelo ser humano para preservar sua vida, baseado 
fundamentalmente na satisfação das necessidades básicas imediatas, como fome, sede e procriação. Para satisfazêlas, o ser humano primitivo busca a companhia de outros, agrupando-se com seus semelhantes. Uma vez satisfeitas tais necessidades, ele volta inevitavelmente a viver no estado de isolamento, caracterizado pela indolência natural. Portanto, o amor de si é o estado pré-racional, présocial e pré-moral do homem primitivo, caracterizando sua condição de isolamento e independência.

No entanto, por razões naturais, sobretudo, por um "funesto azar", a situação transforma-se radicalmente e o ser humano deixa de procurar seu semelhante somente para atender suas necessidades imediatas. Ao desenvolver "necessidades espirituais", não pode mais viver sem a companhia permanente do outro, mesmo que tal companhia lhe signifique uma ameaça constante. Dá-se, com isso, o passo irreversível para a sociedade e, com ela, à necessidade das instituições, da cultura e da própria educação. Não podendo mais viver isolado e para evitar que o outro seja uma ameaça constante à sua própria conservação física, o ser humano é impulsionado a criar leis e instituições. As leis cumprem, desse modo, ao menos no plano normativo, o papel de colocar todos iguais um diante do outro, isto é, com os mesmos direitos e deveres.

O fato é que, na vida em sociedade, o ser humano não se contenta mais com a satisfação de suas necessidades básicas. Nesta nova condição, não lhe basta mais simplesmente comer, dormir e procriar. O que não the basta mais, em última instância, é o sentimento do amor de si e a piedade natural a ele vinculada. Justamente aí é que se faz compreender o papel do amor-próprio. Seu surgimento é concomitante ao nascimento social do homem. Como descreve Rousseau, no Segundo Discurso, em um linguajar quase poético, encontrando-se na sombra do carvalho, o homem primitivo já despertou o sentimento de inveja, ao ver seu semelhante possuir um corpo mais bonito e dançar melhor do que ele (OC III 169; 1978, p. 263). Aquele que dança melhor, por sua vez, arvora-se ao direito de ocupar uma posição superior, se sentindo inclusive feliz por ver seu semelhante diminuído.

Amparando-se em certas passagens do texto de Rousseau, Fetscher destaca a dinâmica altamente perigosa e destrutiva que o amor-próprio assume no processo de socialização humana. O ser humano, deixando-se orientar somente por seu amor-próprio, elege a si mesmo como fim exclusivo, transformando os outros em simples meio para seus interesses egoístas. Em sua interpretação, Fetscher alicerça o amor-próprio só na razão calculista, ${ }^{5}$ que instrumentaliza os outros para fins privados. Desse modo, os relacionamentos humanos e sociais orientados pela racionalidade do amor-próprio tornam-se destrutivos. Em síntese, o amor-próprio é negativo porque, dirigido pela razão calculista, torna-se a fonte dos vícios e da maldade humana, significando então a destruição da ordem natural e social. ${ }^{6}$ Em uma passagem de seu texto, Fetscher acentua nitidamente esta perspectiva: "Do amorpróprio surgem paixões e conflitos que tornam impossível a vida humana social e comunitária" (FETSCHER, 1975, p. 92). Do amor-próprio brotam indivíduos absolutamente egoístas, incapazes de viver solidariamente com os outros.

Fetscher está coberto de razão ao acentuar a variante negativa do amor-próprio e o potencial altamente perigoso e destrutivo que ele representa à formação da condição humana e sua respectiva socialização. Esta sua análise encontra amplo amparo textual no próprio pensamento de Rousseau. Reconhecidamente, é em seus escritos de crítica à cultura que o genebrino mostra o quanto os sentimentos de vaidade, ódio, raiva e arrogância humana se entrelaçam profundamente com a corrupção social e institucional, pondo seriamente em risco a própria existência humana.

Não só o Segundo Discurso, como também a Carta a D'Alambert esclarece em que termos a variante negativa do amor-próprio traz em si um potencial destrutivo. O teatro, talvez mais do que qualquer outra manifestação cultural, desenvolve a lógica perversa do "parecer", sobrepondo-a ao sentido humano de autenticidade que repousa na lógica do "ser". Ou seja, a peça teatral, por meio da influência que seus atores exercem no imaginário da plateia, fortalece o mundo da aparência, fazendo com que os espectadores se satisfaçam mais com aquilo que "parecem ser" do que realmente são. Nesse sentido, o teatro - e Rousseau tinha em mente o teatro parisiense de sua época -, ao aguçar o lado pervertido do amor-próprio, tornava-se uma das principais forças propulsoras da artificialidade social, distanciando o povo dos autênticos valores republicanos (ROUSSEAU, 1994). ${ }^{7}$

Precisamos ter em mente, de outra parte, que a variante destrutiva do amor-próprio não se encontra somente nos escritos de crítica à cultura. Ela também aparece soberanamente nos escritos educacionais, especialmente no Émile. Podemos encontrar neste texto uma farta documentação sobre o aspecto corrosivo que o amorpróprio descontrolado exerce na vida dos indivíduos, sobretudo, nas situações em que eles se deixam dominar por suas paixões maldosas. O Émile possui inúmeros exemplos do modo como os adultos, deixando-se orientar pelo seu amor-próprio pervertido, corrompem e estragam as crianças, privando-as de um preparo adequado para enfrentar o mundo. Famílias desestruturadas, com pais que buscam a satisfação de seu amor-próprio somente no mundo externo, dando interesse apenas ao glamour da vida em salões, se descuidam das questões simples e indispensáveis à educação inicial das crianças. Eles se tornam responsáveis, em certo sentido, pelo possível 
fracasso das crianças, comprometendo já na infância sua vida virtuosa futura.

Com isso fica claro então que, ao acentuar o aspecto negativo do amor-próprio, a interpretação de Fetscher está de acordo com o texto de Rousseau. O problema, contudo, não reside aí, mas sim no fato de ter ignorado a variante construtiva do amor-próprio. Antes de mostrar, com o auxílio de Neuhouser, a existência de tal variante no texto de Rousseau e analisar seu significado à teoria educacional, gostaria de me manter ainda mais um instante na companhia de Iring Fetscher, para, também com seu auxílio, reconstruir um aspecto nuclear da teoria da virtude de Rousseau, a qual retomarei posteriormente.

Um dos méritos da interpretação de Fetscher repousa em ter destacado o papel que a noção de consciência desempenha na justificativa rousseauniana da virtude. Rousseau insere-se numa longa tradição intelectual segundo a qual a ação virtuosa depende da capacidade humana de dominar suas paixões. Ou seja, ele viu muito bem o quanto a condição frágil e vulnerável do ser humano o empurra a agir movido pela força de suas paixões odientas e irascíveis. Percebeu também que se não for contraposta a ela uma força antagônica construtiva, a humanidade caminha para sua própria destruição. Rousseau denomina de virtude o núcleo desta força, elegendo a consciência como seu impulso condutor. A consciência, embora de sentido complexo e obscuro, é compreendida por Rousseau, em algumas passagens do quarto livro do Émile, como o profundo sentimento de amor à ordem que o ser humano carrega dentro de si e que lhe serve de espelhamento para fazer frente às paixões maldosas. Este amor à ordem materializa-se no amor à justiça, provocando então a formação da consciência virtuosa.

Em síntese, deixando-se inspirar pelo amor à ordem, o ser humano sobrepõe-se à força de suas paixões maldosas, elevando sua ação ao âmbito da virtude. Neste sentido, virtude nada mais é do que a capacidade humana de dominar as paixões maldosas que emergem do amorpróprio. Homem virtuoso então é aquele que é capaz de romper com seu egoísmo, incluindo a perspectiva da humanidade em sua própria ação individual. Fetscher insiste também, neste contexto, que em termos políticos, a virtude significa a identificação entre vontade individual e vontade geral, marcando com isso a coincidência entre ética e política: homem virtuoso é o cidadão ideal na medida em que não defende seus interesses privados egoístas, mas sim os interesses elevados de seu eu ético representado pelo ponto de vista da vontade geral (ibidem, p. 93).

O leitor poderia objetar aqui, nesta altura de minha argumentação, que a consciência não é a fonte exclusiva da motivação moral do ser humano. Tal objeção encontra amparo textual no livro quarto do Émile (OC IV, 522523), onde Rousseau põe a compaixão (piedade) como fonte de nossa direção à generosidade e à justiça, sem o auxílio da consciência. Ou seja, teríamos então uma propensão inata à justiça que independeria da consciência. Com interpretar isso? Temos aqui uma dificuldade nuclear do texto de Rousseau e que é mais uma prova de seu estilo aporético. Nesse sentido, não podemos esquecer que também no interior do mesmo livro quarto do Émile Rousseau concebe a consciência como verdadeira guia do ser humano. Se a consciência é esse guia maior que conduz o ser humano à justiça, então somos levados a crer que a própria compaixão, enquanto sentimento que também orienta a ação humana à justiça, não pode estar desvinculada da consciência.

Em síntese, antes de concebermos compaixão e consciência como duas forças humanas antagônicas entre si, devemos vê-las como possuindo uma base comum. Esta é a posição adotada por Nicolas Dent:

É agora possível ver como acontece que os sentimentos engendrados por compaixão e as instigações da consciência têm, em última instância, uma raiz comum para Rousseau: em ambos os casos, é a nossa própria constituição instruindo-nos para obedecer à nossa própria natureza e ao bem que está sendo expressado (DENT, 1996, p. 79, grifos meus).

No contexto de nossa interpretação, essa raiz comum que constitui a compaixão e a consciência deixa-se compreender pelo recurso à ambiguidade do amorpróprio. Isto é, na base de "nossa própria constituição" está a dupla variante do amor-próprio: como negativa, pois é excessivamente inflamada (petulante e vaidosa) e; como positiva, enquanto amor à justiça, dirigida ao bem. Ora, por pensar somente na conexão entre amor de si, compaixão e amor à justiça e ver no amor-próprio somente um sentimento destrutivo, Fetscher desconsidera a base comum entre compaixão e amor de si e, mais ainda, ignora a variante construtiva do amor-próprio.

Dessa breve reconstrução ficam evidentes dois limites da interpretação de Fetscher: não considera a variante positiva do amor-próprio, ignorando sua potencialidade construtiva e; ao ver na consciência que contempla o esplendor do amor à ordem a principal solução encontrada por Rousseau para fazer frente ao amor-próprio maldoso, deixa de colocar no centro o que de fato é a solução, ou seja, a saída formativa da vontade humana baseada na educação do amor-próprio. Fetscher ignora, em síntese, o papel que o amor-próprio construtivo desempenha na ligação entre consciência e amor à ordem, mantendo em um plano meramente ideal aquilo que Rousseau procurou concretizar por meio da relação normativa entre educador e educando. 
No próximo passo de minha argumentação pretendo evidenciar a força construtiva do amor-próprio e analisar brevemente como ela pode se efetivar na ação humana por meio da educação virtuosa. Desse modo, segundo penso, Rousseau acreditou firmemente que o fortalecimento da dimensão construtiva do amor-próprio por meio da virtude seria a resposta mais promissora para enfrentar a maldade humana e a corrupção social e política.

\section{EdUCAÇÃo PARA A VIRTUde}

Com a reconstrução da interpretação de Fetscher desenvolvida acima, foi possível deixar claro que Rousseau concebeu o amor por si mesmo como impulso fundamental do ser humano, desdobrando-o em amor de si e amor-próprio. Fetscher viu acertadamente o quanto foi decisivo para o genebrino vincular o amorpróprio maldoso à condição humana que se desenvolve socialmente. Nesse sentido, Rousseau estava convencido que não podemos compreender o fenômeno da alienação humana e da corrupção social se não prestarmos atenção à lógica destrutiva do amor-próprio, baseada nas paixões maldosas. Mas Fetscher não viu a ambiguidade do amorpróprio, pois ignorou sua potencialidade construtiva e, por desconsiderá-la, não pôde ver o papel formativo (regulativo) que a virtude desempenha na contenção das paixões maldosas.

Em seu estudo Pathologien der Selbstliebe (Patologias do amor-próprio), Frederick Neuhouser reaviva intensamente os estudos sobre o pensamento de Rousseau, permitindo reatualizar o debate sobre vários temas difíceis e caros à comunidade rousseauniana de investigadores. Coloca no centro desta reatualização o amor por si mesmo como núcleo constitutivo da condição humana, destacando a questão da ambiguidade do amor-próprio. Ou seja, o amor por si mesmo é o impulso humano que o impele ao seu próprio bem-estar. Quando tal impulso é natural e destinado exclusivamente à autoconservação, Rousseau o chama de amor de si. Quando é social, dinamizado pela razão e entrelaçando-se com a moralidade, então o amor por si mesmo transforma-se em amor-próprio. A patologia do amor por si mesmo repousa em uma dupla perspectiva: do ponto de vista do amor de si, a dinâmica da autoconservação conduz ao isolamento e independência absoluta; de outra parte, considerando a força destrutiva do amor-próprio, à socialização humana está inerente à busca obcecada por posição superior. O principal antídoto a esta patologia é a formação democrática da vontade, baseada na educação virtuosa.

A novidade da interpretação de Neuhouser, ${ }^{8}$ que permite ser tomada como um corretivo importante à interpretação de Fetscher, despertando enorme atenção de teóricos sociais críticos atuais, como é o caso de
Axel Honneth, repousa na teoria da ambiguidade do amor-próprio. Se tal sentimento não possui apenas uma tendência destrutiva (negativa), mas também positiva, onde ela repousa? Por que Rousseau concebe a educação do amor-próprio como principal recurso para enfrentar a maldade humana e em que termos ele pensa tal educação? Ao deparar-se com estas questões, Neuhouser põe o Émile no centro da arquitetônica do pensamento rousseauniano. Com isso pretende mostrar em que sentido a aparente contradição e descontinuidade entre o diagnóstico social e cultural negativo do Segundo Discurso e o ideal normativo Do Contrato Social, que repousa na ideia republicana constituída por cidadãos e cidadãs livres e iguais, pode ser desfeita quando se tem em mente a centralidade da teoria do amor-próprio.

Em síntese, tudo depende da ambiguidade do amor-próprio. Além de seu aspecto negativo que, como vimos, constitui o núcleo da interpretação de Fetscher, há $o$ aspecto construtivo sem o qual não haveria sociedade, nem estruturas institucionais e nem o poder do Estado. Considerando os males profundos que acometem a vida em sociedade, como a corrupção, a alienação e as diferentes formas de vícios, sem a tendência construtiva do amor-próprio não haveria as mínimas condições para que a vida humana fosse organizada em instituições regidas por leis e costumes. Rousseau analisou com profundidade este fenômeno, segundo Neuhouser, quando considerou a busca por reconhecimento como a mola propulsora da constituição social do si mesmo (Soi-même/Self).

Contudo, antes de ser negativo ou positivo, o amor-próprio é um tipo de sentimento neutro que mostra a característica central do homem vivendo em sociedade, a saber, de almejar ser considerado como ser de valor aos olhos (juízos) dos outros. Assim afirma Neuhouser: "Deste modo, a doutrina do amor-próprio de Rousseau forma uma parte indispensável de sua teoria psicológica como força de impulso fundamental da ação humana" (NEUOHOUSER, 2012, p. 67). Agimos, em primeiro lugar, para assegurar nossa sobrevivência física e, em segundo lugar, para buscar sermos reconhecidos como alguém de valor aos olhos dos outros.

A natureza eminentemente social do amor-próprio, diferentemente do amor de si, torna-o um sentimento relacional e, por isso, não pode ser um sentimento isolado nem absoluto. Rousseau formula aqui uma tese de fundo, que servirá de base tanto para sua teoria educacional como para sua filosofia moral e política, a saber, de que é esta condição relacional e relativa do amor-próprio que dá ao ser humano o sentimento de sua própria existência. Isso significa dizer, em outros termos, que o sentido da vida humana só pode ser construído em espaços sociais e institucionais, não podendo haver ação significativa, com sentido, fora da sociedade. Neuhouser resume o sentido 
relacional do amor-próprio numa dupla perspectiva: na necessidade humana de comparar-se permanentemente com os outros e na dependência que cada ser humano possui em relação ao julgamento dos outros. Em qualquer uma destas duas perspectivas está clara a dependência recíproca que caracteriza a sociabilidade humana.

A satisfação do ser humano como um ser social e isso, segundo Neuhouser, constitui o núcleo da teoria do reconhecimento de Rousseau - só ocorre mediante a estima pública. Querer ser reconhecido e estimado pelos outros é algo que forma o mais profundo nível de satisfação do ser humano, que está muito além da supressão de suas necessidades imediatas. Neste sentido, se o amor-próprio amplia indefinidamente as potencialidades do fracasso e da frustração humana, também aumenta as possibilidades de realização do sentimento autêntico de sua própria existência.

A dinâmica destrutiva do amor-próprio acentua-se, tornando-se força dominante da sociabilidade humana, quando o desejo humano vincula-se exclusivamente com o querer ser a qualquer custo melhor do que os outros, ou seja, com o querer ocupar uma posição superior em relação a eles. O "querer ser superior" está na origem da arrogância, da vaidade, do ódio e da inveja. Isso está claro no texto de Rousseau e foi destacado por Fetscher acertadamente. Contudo, Rousseau não foi só pessimista e menos ainda fatalista, pois concebeu que se a busca por estima está diretamente vinculada à comparação com os outros, não lhe é intrínseco, como algo absoluto e irreversível, o desejo de querer ser superior aos outros. Esta relativização que a interpretação de Neuhouser permite em relação à dinâmica destrutiva do amorpróprio torna-se indispensável para se compreender o alcance e a validade da proposta educativa desenvolvida por Rousseau visando tratar do problema da maldade humana e da corrupção social e política. Ou seja, foi justamente por ter atribuído uma dimensão construtiva ao amor-próprio que Rousseau pôde conceber o esboço de sua teoria educacional desenvolvida no Émile como "corretivo" à visão pessimista que predomina em seus escritos de crítica à cultura.

Para Neuhouser (ibidem, p. 96), não há duvida de que a vontade humana de dominação, alicerçada no desejo de querer ser superior ao outro, só pode ser enfrentada adequadamente pela educação e, mais especificamente, por uma educação baseada na virtude. Neste sentido, o Émile se constitui em um projeto educacional poderoso e ainda atual em muitos aspectos, na medida em que idealiza normativamente uma forma de relação entre educador e educando com o intuito claro de evitar a proliferação do amor-próprio destrutivo (inflamado). Rousseau viu, como nenhum outro autor moderno, a tensão inerente à condição humana: por um lado, o ser humano aspira ser reconhecido pelo outro, como um ser de superioridade inquestionável; por outro, também se deixa mover pelo amor-próprio igualitário, ou seja, pelo sentimento de que todos devem possuir igual valor (ibidem, p. 163).

Neste contexto, a convicção de fundo de Rousseau é que o amor-próprio carrega em si uma força construtiva à sociabilidade humana. Este potencial construtivo se deixa manifestar, sobrepondo-se à busca obsessiva pela superioridade (vontade de dominação), quando o amorpróprio é estendido até a virtude. Rousseau expressa isso lapidarmente em uma passagem do Émile: "Estendendo o amor-próprio sobre os outros seres, nos o transformaremos em virtude, e não há coração humano em que esta virtude não tenha raiz" (OC IV 547; 1992, p. 288). Mas o que significa esta ideia da extensão do amor-próprio? Significa a capacidade humana de ver as coisas também pelo ponto de vista dos outros. Mais ainda, significa a aceitação ética de que a formação de seu eu autêntico, de seu si mesmo (Self/Selbst), depende do reconhecimento do outro. Na contramão disso, o amor-próprio petulante é o tipo de sentimento que conduz o ser humano para dentro de seu casulo, impossibilitando-o de ver o que está além de sua mira egoísta, só incluindo o outro para seus próprios interesses, privados e individualistas. Ou seja, nas palavras de Rousseau, "[o ser humano] mau ordena o todo em relação a si mesmo" (OC IV 602).

Neste contexto, a virtude é o ponto de vista de que a formação autêntica do si mesmo só ocorre mediante a dependência recíproca de sujeitos iguais entre si: o si mesmo que considera o outro como parceiro solidário, sendo assim também tomado por tal parceiro. Como afirma Dent: "Só num relacionamento entre iguais, onde cada um valoriza e estima o outro e cada um sente seu próprio valor e poder, é possível ser encontrado o verdadeiro reconhecimento humano" (DENT, 1996, p. 69). É justamente neste momento que a virtude transforma-se no amor à humanidade, o qual, enquanto amor à justiça se encarna nas relações sociais e políticas. Para Rousseau, o amor à justiça exige o respeito recíproco entre iguais, ou seja, o respeito à singularidade de cada um, que o torna diferente em relação aos outros. Neste sentido, é o princípio da justiça baseado na igualdade que assegura o ponto de vista da pluralidade.

Quando Rousseau é interpretado dessa maneira, está muito longe de ser o teórico do "Estado totalitário" ou o simples pioneiro do "sujeito racional autônomo", baseado em um modelo único de racionalidade. Ao formular uma teoria do reconhecimento com base no princípio da justiça como igualdade, Rousseau abre, a meu ver, um veio fecundo para pensar o problema da pluralidade humana: o si mesmo (soi-même) só pode ser reconhecido em sua singularidade e naquilo que o constitui como ser único, diferente dos outros, com base na aceitação de que é igual 
aos outros, ou seja, de que possui o mesmo direito que os outros possuem de ser reconhecido. De outra parte, significativo aqui é o fato de que a singularidade do si mesmo depende do reconhecimento do outro e, nesse sentido, a pluralidade que repousa no fato de que cada si mesmo é diferente do outro só pode ser garantida (reconhecida) publicamente, ou seja, pela presença e testemunho do outro. ${ }^{9}$

De qualquer forma, com a teoria do amor-próprio Rousseau desvelou um aspecto nuclear da condição social humana, mostrando o quanto ela põe de exigência ao próprio ser humano, sendo fonte de seus desgostos e decepções, mas também de suas possíveis realizações. Mostrou em forma de esboço, no livro quinto do Émile, o quanto a extensão do amor-próprio até a virtude é indispensável para regular a vida republicana, livre e democrática, do cidadão Emílio. Do ponto de vista político, Rousseau está convencido que a formação do homem virtuoso é condição indispensável da obediência livre do cidadão à lei republicana. De outra parte, do ponto de vista da arquitetônica pedagógica, ou seja, de um olhar sobre o Émile como um todo, mostrou que a teoria positiva da virtude - ou seja, a ampliação do amor-próprio sobre os outros seres - é precedida pela teoria negativa, desenvolvida nos três primeiros livros da referida obra. Se a maior preocupação de Rousseau também se concentra na educação do amor-próprio petulante, contudo, ele a desenvolveu na forma de contenção do desabrochamento precoce do amor-próprio. Desse modo, ele desenvolveu em seu projeto de educação natural os princípios e as diretrizes gerais de uma teoria negativa da virtude, visando manter o aluno fictício distante dos vícios.

Contenção e ampliação do amor-próprio, teoria negativa e positiva da virtude são duas faces de uma mesma moeda que visa à formação tanto do homem como do cidadão. A contenção do amor-próprio por meio da teoria negativa da virtude visa formar o ser humano autônomo e independente, capaz de pensar por conta própria. A ampliação do amor-próprio através da virtude significa a obrigação do ser humano de agir livremente impelido pelo amor à justiça, considerando-se a si mesmo como igual entre iguais. Deste modo, a unidade do projeto homem-cidadão encontra-se no sentido de que o cidadão que se deixa orientar livremente pela força da lei tem como base de sustentação sua capacidade de julgar por si mesmo, capacidade esta que o habilita inclusive para, quando necessário, recriar e reinventar a própria lei. Ou seja, o ponto é que sem maioridade não há vida republicana de sujeitos livres e iguais, que constituem sua pluralidade respeitando-se em suas próprias diferenças.

Resumindo, como podemos observar, a interpretação de Neuhouser complementa a leitura de Fetscher em um ponto central. Ao mostrar a força construtiva inerente ao amor-próprio, Neuhouser pôde destacar o alcance da teoria educacional do Émile. Com isso também pôde deixar claro, enquanto tendência marcante do pensamento pedagógico de Rousseau, a indispensabilidade da virtude para conter o alastramento do amor-próprio pervertido (maldoso), ou seja, das paixões humanas odientas e irascíveis.

\section{CONSIDERAÇÕES CONCLUSIVAS}

O duplo exercício, por um lado, de interpretação cuidadosa do texto clássico e, por outro, do esforço em atualizá-lo, é indispensável à compreensão sobre a problemática educacional atual. O poder inesgotável do texto clássico repousa justamente na sua capacidade de cruzar fronteiras, indo além do tempo histórico do próprio autor. O texto torna-se clássico porque consegue antecipar de forma espantosa problemas que apenas muitos séculos depois ganham configuração mais definida. Ao lê-los, temos a impressão de que foram escritos exatamente para nós e para nossa época. Assim se passa, por exemplo, com a República de Platão ou com o Émile de Rousseau, para ficar tão somente em dois dos casos mais expressivos.

Mas o diálogo com o texto clássico, além de ser inesgotável, exige muita paciência e esforço. Nem todos os autores se tornam clássicos, pois só uma mente muito vigorosa e criativa é capaz de elaborar ideias que continuam influenciando a humanidade, geração após geração. Podemos imaginar que, se são somente os grandes autores a escrever o texto clássico, nosso acesso a ele não pode ocorrer nem direta e nem instantaneamente. Por isso, precisamos geralmente da mediação de especialistas, que podem nos auxiliar pedagogicamente no ingresso aos problemas abordados por tais autores. Além disso, há a singularidade da relação que cada época ou geração estabelece com o autor clássico, permitindo-lhe fazer suas próprias interrogações e descobertas. Embora isso aconteça mais com alguns autores do que com outros, no caso de Rousseau torna-se evidente. Jean Starobinski, que já se tornou ele próprio um especialista clássico sobre o pensamento de Rousseau, descreve bem este fenômeno:

Com ele, não se termina nunca: é preciso sempre recomeçar de uma maneira nova, reorientar-se ou desorientar-se, esquecer as fórmulas e as imagens que no-lo tornavam familiar e nos davam a tranquilizadora convicção de tê-lo definido de uma vez por todas. Cada geração descobre um novo Rousseau, em quem encontra o exemplo do que ela quer ser, ou do que recusa apaixonadamente (STAROBINSKI, 1991, p. 277).

Portanto, podemos aprender muito com a companhia privilegiada dos clássicos, destacando-se como aspecto 
importante desta formação, entre outros, a necessidade de um pensar paciencioso. Os autores clássicos são aqueles que nos auxiliam a pensar o processo formativo humano não como uma tecnologia educacional, mas sim como uma "questão educacional", pois impedem que a educação seja reduzida simplesmente à aprendizagem (BIESTA, 2013, p. 29-53). Desse modo, nos ensinam o quanto precisamos evitar a instrumentalização da teoria e do pensamento, pois nos mostram a periculosidade da pressa e do imediatismo na busca de solução para nossos problemas. Rousseau, especialmente, ao escavar fundo na investigação da condição humana, descobriu a dinâmica destrutiva do amor-próprio, ou seja, da força perversa que as paixões maldosas exercem na sociabilidade humana, corrompendo o ordenamento moral, político e jurídico. ${ }^{10}$ Mostrou, dessa forma, a profunda imbricação entre as paixões maldosas e a corrupção social e política.

O fascínio que ainda exerce sobre nós reside, em boa parte, no fato de ter apostado no projeto educacional e na vida republicana como maneira mais eficiente de enfrentar a imbricação explosiva entre paixões maldosas e corrupção social e política. Considerando as profundas transformações históricas que dele nos separam, obviamente que não podemos querer transpor literalmente seus ideais para o nosso tempo. Mas isso não nos impede de tomar como modelo instrutivo o nexo por ele pensando entre educação e república. Deveríamos levar a sério então, neste contexto, sua profunda convicção de que uma vida republicana de sujeitos livres e iguais é resultado do inesgotável esforço de educação virtuosa das novas gerações. Longe de um moralismo autoritário, a educação virtuosa exige a capacidade de se colocar no lugar do outro e de aprender a conviver com pontos de vista diferentes. Isso implica, como Rousseau tratou no quarto livro do Émile, uma educação do gosto que compreenda os sujeitos em sua própria ação e experiência. Sem grandes espetáculos, sem pompa e sem luxo, tal educação exige a simplicidade e o senso de moderação, pois são estes "pequenos" valores que educam a vontade humana contra sua própria inclinação forte à superioridade patológica e destrutiva.

Contra a vontade doentia de dominação não há alternativa senão o sentimento de existência baseado no respeito recíproco, ou seja, na consideração de que somos iguais em respeito às nossas diferenças. Em síntese, Rousseau estava convencido que a melhor forma de assegurar a pluralidade da condição humana seria atacar de frente a nefasta propensão humana à superioridade. Ora, o discernimento acerca da "questão educacional" seria, neste contexto, uma das formas mais eficiente para tratar da condição social humana patologicamente afetada pela vontade de dominação. É isso que significa, em últimas palavras, seu enorme esforço empreendido no Émile de delinear os princípios pedagógicos gerais de educação do amor-próprio pervertido.

Em síntese, espero ter conseguido exemplificar, neste ensaio, por meio da investigação do conceito de amor-próprio - um conceito-chave do pensamento de Rousseau -, o quanto o estudo do pensador clássico é fundamental para compreender nossa própria condição humana. Se o estudo paciencioso do pensador clássico leva à compreensão de nós mesmos, de nossa situação no mundo, de nossas angústias e aspirações, então seu estudo é indispensável à formação de novas gerações. Contudo, o estudo do clássico precisa se acercar de interpretações especializadas, pois uma interpretação mostra os limites da outra e, nesse sentido, complementa-a de maneira indispensável. Como podemos observar, se nos mantivéssemos somente na interpretação de Fetscher, sem tê-la contraposta à interpretação de Neuhouser, não poderíamos compreender a educabilidade do amorpróprio como tarefa pedagógica principal do Émile. Com isso, teríamos privado as novas gerações de ter acesso a uma das contribuições mais importantes da pedagogia moderna, que ainda respinga, de maneira vigorosa, no debate pedagógico contemporâneo. Pois, o tratamento aprofundado da formação do ser humano nos conduz à reflexão da condição humana $\mathrm{e}$, nesse sentido, ao pensamento sobre a ambiguidade do amor-próprio: como fonte de nossas paixões odientas e irascíveis, mas, também, de nossa motivação moral para o reconhecimento do outro.

\section{REFERÊNCIAS}

BIESTA, Gert. Para além da aprendizagem: educação democrática para um futuro humano. Tradução de Rosaura Eichenberg. Belo Horizonte: Autêntica, 2013.

DALBOSCO, Claudio Almir. Aspiração por reconhecimento e educação do amor-próprio em Jean-Jacques Rousseau. Educação e Pesquisa, v. 37, n. 3, p. 481-496, set./dez. 2011.

DALBOSCO, Claudio Almir. Pesquisa educacional e experiência humana na perspectiva hermenêutica. Cadernos de Pesquisa, v. 44, n. 154, p. 1028-1051, 2014a.

DALBOSCO, Claudio Almir. Condição humana e formação virtuosa da vontade: profundezas do reconhecimento em Honneth e Rousseau. Educação e Pesquisa (USP), v. 40, n. 3, p. 799-812, 2014b. http://dx.doi.org/10.1590/s151797022014091625

DENT, Nicolas. J. H. Dicionário Rousseau. Rio de Janeiro: Jorge Zahar, 1996.

FETSCHER, Iring. Rousseaus politische Philosophie: Zur Geschichte des demokratischen Freiheitsbegriffs. Frankfurt am Main: Suhrkamp, 1975.

FLICKINGER, Hans-Georg. A caminho de uma pedagogia hermenêutica. Campinas: Autores Associados, 2010. 
FUCHS, Hans-Jürgen. Entfremdung und Narzissmus: Semantische Untersuchungen zur Geschichte der "Selbstbezogenheit" als Vorgeschichte von französisch "amour-propre”. Stuttgart: Metzler, 1977.

HERMANN, Nadja. Hermenêutica e educação. Rio de Janeiro: DP\&A, 2003.

HONNETH, Axel. Das Recht der Freiheit. Grundriss einer demokratischen Sittlichkeit. Frankfurt am Main: Suhrkamp, 2011 .

HONNETH, Axel. Untiefen der Anerkennung. Das sozialphilosophische Erbe Jean-Jacques Rousseau. WestEnd, Neue Zeitschrift für Sozialforschung, 9(2012a) 1-2, 47-64.

NEUHOUSER, Frederick. Pathologien der Selbstliebe: Freiheit und Anerkennung bei Rousseau. Frankfurt am Main: Suhrkamp, 2012.

REBENTISCH, Juliane. Die Kunst der Freiheit: Zur Dialektik demokratischer Existenz. Frankfurt am Main: Suhrkamp, 2013.

ROUSSEAU, Jean-Jacques. Oeuvres complètes. Paris: Gallimard, Bibliothèque de la Plêiade, 5 tomos, 1959-1995.

ROUSSEAU, Jean-Jacques. Discurso sobre a origem e os fundamentos da desigualdade entre os homens. Tradução de Lourdes Santos Machado. Col. Os Pensadores. São Paulo: Abril Cultural, 1978.

ROUSSEAU, Jean-Jacques. Emílio ou da Educação. Tradução de Sérgio Milliet. Rio de Janeiro: Bertrand Brasil, 1992.

ROUSSEAU, Jean-Jacques. Carta a D'Alembert. Tradução de Quintín Calle Carabias. Madrid: Tecnos, 1994.

ROUSSEAU, Jean-Jacques. Emil oder Über die Erziehung. Übersetzung von Martin Rang. Stuttgart: Reclam, 2004.

STAROBINSKI, Jean. A transparência e o obstáculo. São Paulo: Companhia das Letras, 1991.

TAYLOR, Charles. A ética da autenticidade. São Paulo: É Realizações Editora, 2011.

\section{Notas}

${ }^{1}$ Cabe ressaltar, contudo, que o procedimento hermenêutico não se limita à relação entre leitor (investigador) e texto, mas abarca a experiência humana em seu sentido amplo, atendo-se especialmente ao diálogo vivo entre duas ou mais pessoas. Para uma abordagem específica da relação entre hermenêutica e educação, consultar Nadja Hermann (2003).

2 Procuro tratar da pergunta como aspecto estruturante do problema de investigação no ensaio "Pesquisa educacional e experiência humana na perspectiva hermenêutica" (DALBOSCO, 2014a).

3 Em ensaio recente, deixando-se inspirar pela nova interpretação de Frederick Neuhouser, Honneth considera Rousseau como pai da teoria do reconhecimento (HONNETH, 2012). Ocupei-me criticamente com a interpretação de Axel Honneth no ensaio "Condição humana e formação virtuosa da vontade: profundezas do reconhecimento em Honneth e Rousseau" (DALBOSCO, 2014b, p. 799-812).

${ }^{4}$ Abreviatura da obra Discurso sobre a origem e os fundamentos da desigualdade entre os homens.

${ }^{5}$ Segundo Fetscher, Rousseau argumenta no mínimo com dois conceitos de razão: o primeiro, é o sentido calculista que está a serviço das paixões sensíveis; o segundo sentido refere-se à capacidade do conhecimento da ordem, relacionando-se à distinção medieval (Tomas de Aquino) entre ratio como faculdade do pensamento discursivo e intellectus como faculdade dos princípios (FETSCHER, 1975, p. 82)

6 Além de considerar somente a negatividade do amor-próprio, Fetscher comete também o erro de desconsiderar a base antropológica da razão instrumental e seu papel necessário à autoconservação humana. Em trabalho recente, Charles Taylor (2011), além de mostrar a natureza antropológica da razão instrumental, também destaca seu papel construtivo à ética da autenticidade, desde que devidamente limitada.

7 Segundo Juliane Rebentisch, a crítica que Rousseau desenvolve ao teatro tem preocupações éticas e políticas bem determinadas, pois o jogo teatral corrompe a autenticidade social séria (REBENTISCH, 2013, p. 274).

8 Resumo aqui de maneira livre a reconstrução detalhada da interpretação de Neuhouser que empreendi no ensaio "Aspiração por reconhecimento e educação do amor-próprio em Jean-Jacques Rousseau” (DALBOSCO, 2011, p. 481-495).

9 Com esta linha de raciocínio me oponho ao juízo generalizante que Gerd Biesta (2013) formula da educação moderna.

${ }^{10}$ É bem verdade que o amor-próprio não é uma invenção propriamente rousseauniana, pois seu pensamento sobre o tema se insere, como mostrou Hans-Jürgen Fuchs, em uma longa tradição que remonta à antiguidade grega e à Patrística. Fuchs dedica o último capítulo da referida obra para tratar do amour propre no século XVIII, concentrando-se no pensamento de Rousseau (FUCHS, 1977, p. 267-292).

Artigo recebido em janeiro 2014

Aprovado em fevereiro 2015 . 